\title{
Role of Hippocampal CaMKII in Serotonin 5-HT IA Receptor-Mediated Learning Deficit in Rats
}

\author{
Sonia Moyano', Joaquín Del Río*,' and Diana Frechilla' \\ 'Department of Pharmacology, School of Medicine, University of Navarra, Apartado 177, Pamplona, Spain
}

\begin{abstract}
The serotonin 5-HTIA receptor agonist, 8-OH-DPAT (8-hydroxy-2-di-n-propylamino-tetralin), impairs retention performance in a passive avoidance learning task in rats. In the hippocampus of rats trained on this procedure and killed I $\mathrm{h}$ after the acquisition trial, an increase in the membrane levels of both $\mathrm{Ca}^{2+}$ /calmodulin-dependent protein kinase II (CaMKII) and phosphorylated CaMKII, as well as in total and $\mathrm{Ca}^{2+}$-independent enzyme activity in tissue lysates was found. These effects were learning-specific as no changes in CaMKII levels or activity were found in rats receiving a footshock identical to the trained rats. The effect of training on CaMKII was prevented by a low 8-OH-DPAT dose. The 5-HTIA agonist also reduced protein kinase A (PKA) activity and increased the membrane levels of phosphatase I (PPI) and PPI enzyme activity in the hippocampus. All of the changes induced by 8-OH-DPAT were reversed by the selective 5-HT IA antagonist WAY-100635, indicating receptor-specific effects. We suggest that 5-HT IA receptor-mediated disruption of retention performance is a consequence of the reduced PKA activity and the ensuing enhancement in PPI activity, possibly through decreased phosphorylation/activation of endogenous PPI inhibitors, that cause a reduced activity of phosphorylated CaMKII, a key enzyme in early stages of memory formation. This study provides an in vivo molecular basis for the cognitive deficits induced by stimulation of hippocampal $5-\mathrm{HT}$ IA receptors.

Neuropsychopharmacology (2004) 29, 2216 -2224, advance online publication, 16 June 2004; doi: I 0. I 038/sj.npp. 1300504
\end{abstract}

Keywords: memory; kinase; phosphatase; CaMKII; 5-HT IA receptors; hippocampus

\section{INTRODUCTION}

Numerous intracellular signaling pathways with different time courses are activated during the acquisition and consolidation of memory. It seems that early changes are dependent on modifications of pre-existing proteins, probably affecting their phosphorylation state, whereas the later phase is associated to gene expression (Milner et al, 1998). The critical role of glutamate transmission in the early stages of hippocampal-dependent memory storage and in long-term potentiation (LTP) has been extensively documented (Bliss and Collingridge, 1993; Riedel et al, 2003). In synaptic plasticity underlying memory storage, other neurotransmitter systems may also exert an influence, probably through interactions with glutamate.

Serotonin (5-hydroxytryptamine, 5-HT) regulates different forms of synaptic plasticity both during development and in the adult brain (Mazer et al, 1997). In particular, a major role for the serotonergic system in modulating

*Correspondence: Dr J Del Río, Department of Pharmacology, University of Navarra Medical School, Apartado 177, 3 I 080-Pamplona, Spain, Tel: + 34948 425600, Fax: + 34948425649 ,

E-mail: jdelrio@unav.es

Received 23 September 2003; revised II May 2004; accepted 12 May 2004

Online publication: I5 May 2004 at http://www.acnp.org/citations/ Npp05 I 50403438/default.pdf learning and memory has been suggested (eg review by Buhot, 1997). Yet, the nature of the role of the serotonergic system in cognition is not clear, and strategies in which whole brain 5-HT levels were increased or decreased have led to some inconsistent results (Buhot, 1997; Misane and Ögren, 2000). The diversity of 5-HT receptor subtypes has led to explore more specifically the contribution of 5-HT to cognitive processes. Among the 15 subtypes of mammalian 5 -HT receptors, much attention has been paid to the $5-\mathrm{HT}_{1 \mathrm{~A}}$ receptor, highly expressed in limbic areas related to memory storage, particularly in the hippocampus (Pazos and Palacios, 1985). In general, systemic or intrahippocampal administration of the selective $5-\mathrm{HT}_{1 \mathrm{~A}}$ receptor agonist 8-OH-DPAT (8-hydroxy2 -di- $n$-propylamino-tetralin) before training impairs memory retention $24 \mathrm{~h}$ later in different experimental tasks, including passive avoidance (Carli et al, 1992; Otano et al, 1999; Misane and Ögren, 2000). This effect has been generally related to direct stimulation of postsynaptic receptors located on excitatory hippocampal neurons (Carli and Samanin, 1992; Mendelson et al, 1993). Serotonin, as well as the selective $5-\mathrm{HT}_{1 \mathrm{~A}}$ agonist 8 -OH-DPAT, also inhibit LTP induction (Corradetti et al, 1992; Edegawa et al, 1998), an effect that can be blocked by $5-\mathrm{HT}_{1 \mathrm{~A}}$ receptor antagonists, indicating the role of this receptor subtype in 5$\mathrm{HT}$ effects. Other reports have shown that $5-\mathrm{HT}_{1 \mathrm{~A}}$ receptor stimulation inhibits the induction of LTP by suppressing 
NMDA receptor function in postsynaptic neurons (Edegawa et al, 1999).

In LTP induction, there is an early activation of NMDA receptors. Subsequently, a transient $\mathrm{Ca}^{2+}$ entry activates $\mathrm{Ca}^{2+}$-dependent enzymes, leading to long-lasting potentiation of synaptic efficacy. Of particular relevance is the activation of $\mathrm{Ca}^{2+} /$ calmodulin-dependent protein kinase II (CaMKII) that, after autophosphorylation at Thr286, induces crucial molecular events related to synaptic potentiation (Fink and Meyer, 2002), such as phosphorylation of the GluR1 subunit of the AMPA receptor (Barria et al, 1997) and delivery of AMPA receptors to synapses (Shi et al, 2001). The rise in $\mathrm{Ca}^{2+}$ ions may also activate enzymes such as cAMP-dependent protein kinase A (PKA) required for long-term stability of synaptic efficacy (Elgersma and Silva, 1999). Although $5-\mathrm{HT}_{1 \mathrm{~A}}$ receptors are coupled to multiple cell signaling pathways, in the hippocampus, adenylyl-cyclase inhibition appears to be the initial target in $5-\mathrm{HT}_{1 \mathrm{~A}}$ receptor-mediated effects (Schoeffter and Hoyer, 1988).

Even though other brain structures, such as the amygdala (Liang, 1999) or the frontal cortex (Santucci and Shaw, 2003), may contribute to early memory processing of passive avoidance, the sequence of molecular events in the hippocampus associated to learning and retention of passive avoidance tasks appears to be strikingly similar to those underlying other forms of learning and also LTP (reviewed in Izquierdo and Medina, 1997; Shobe, 2002). In an attempt to explore the mechanisms involved in the disruptive effect of $5-\mathrm{HT}_{1 \mathrm{~A}}$ receptor activation on cognition, we sought for targets susceptible to modification by systemic administration of a $5-\mathrm{HT}_{1 \mathrm{~A}}$ receptor agonist to rats subjected to passive avoidance training. On the basis of the presumed $5-\mathrm{HT}_{1 \mathrm{~A}}$ receptor-mediated inhibition of PKA in the hippocampus, a crucial structure in cognitive processes (Milner et al, 1998), we have studied early changes in the expression levels and/or activity of kinases, PKA and CaMKII, and also of protein phosphatase 1 (PP1). PKA indirectly regulates CaMKII through endogenous PP1 inhibitors, and PP1 inhibition results in higher levels of activated CaMKII (Blitzer et al, 1998; Genoux et al, 2002). It was consequently expected that $5-\mathrm{HT}_{1 \mathrm{~A}}$ receptor activation could lead to changes in CaMKII, a key enzyme in memory storage.

\section{MATERIALS AND METHODS}

\section{Animals}

Male Wistar rats (Harlan, Barcelona, Spain) weighing 200-220 g were used. Animals were housed in plastic cages with free access to food and water and maintained in a temperature-controlled environment $\left(21-23^{\circ} \mathrm{C}\right)$ on a $12 \mathrm{~h}$ light/dark cycle. Behavioral experiments were always performed during the light period, from 0900 to 1500 hours. All procedures were in accordance with the guidelines established by the normative of the European Community of November 24, 1986 (86/609/EEC). This study was approved by the Ethical Committee of the University of Navarra (no. 016/01; March 6, 2001).

In biochemical studies, rats were killed by decapitation $1 \mathrm{~h}$ after training (ie $1 \mathrm{~h}$ after the footshock of the acquisition trial; see below). The corresponding controls received identical pharmacological treatments but were not subjected to passive avoidance training. In another control group, rats were directly placed on the grid floor and were killed $1 \mathrm{~h}$ after receiving an identical footshock to the trained rats. The brains were immediately removed and the hippocampi were dissected on ice. In enzyme activity studies, extracts were prepared immediately after the killing and hippocampus dissection. In most Western-blotting studies, hippocampi were frozen on dry ice after dissection and stored at $-80^{\circ} \mathrm{C}$ until use. Given the rapid translocation of CaMKII from the cytosol to the synapses after decapitation (Suzuki et al, 1994), in some Western-blotting experiments, particularly with pCaMKII, the brains were frozen on dry ice before dissection. The results were virtually identical using either procedure.

\section{Drugs and Chemicals}

8-OH-DPAT and $\mathrm{N}$-[2-(4-(2methoxyphenyl)-1-piperaziny1)ethyl]-N-(2-pyridinyl) cyclohexane carboxamide (WAY100635) were from Sigma (USA). Nonidet P-40, leupeptin, and PMSF were from Roche Diagnostics (Germany). All other chemicals were from Sigma (USA). The sources of the antisera, the different enzyme assay kits, and radiochemicals are indicated in the corresponding sections.

\section{Passive Avoidance Learning}

This test was performed according to previously described procedures, using a two-compartment (white/dark) passive avoidance apparatus (Artaiz et al, 1995; Otano et al, 1999). The rat was placed in the illuminated area and $3 \mathrm{~s}$ later, the door was raised. During $90 \mathrm{~s}$, the animal explored the apparatus freely (habituation trial). After $10 \mathrm{~min}$, the rat was placed again in the illuminated chamber. When the rat entered the dark compartment, a guillotine door was closed and after $10 \mathrm{~s}$, the animal was returned to its home cage. After $60 \mathrm{~min}$, the animal was placed again in the white compartment. When the rat entered the dark chamber, the guillotine door was closed again and, after $10 \mathrm{~s}$, an inescapable $2 \mathrm{~mA}$ scrambled electrical foot shock was delivered for $3 \mathrm{~s}$ through the grid floor using a shock generator (training trial). A retention trial was given $24 \mathrm{~h}$ after the acquisition trial by placing the rat in the illuminated compartment and measuring the response latency to re-enter the dark compartment using a cutoff time of $300 \mathrm{~s}$. The $5-\mathrm{HT}_{1 \mathrm{~A}}$ receptor agonist $8-\mathrm{OH}-\mathrm{DPAT}$ $(0.1 \mathrm{mg} / \mathrm{kg}$ s.c.) was given $30 \mathrm{~min}$ before the acquisition trial. The 5- $\mathrm{HT}_{1 \mathrm{~A}}$ receptor antagonist WAY-100635 (0.5 mg/ $\mathrm{kg}$ i.p.) was administered $15 \mathrm{~min}$ before 8-OH-DPAT. Control rats received saline injections by the same route. Animals were assigned at random to the different treatments.

\section{Production of Protein Extracts}

To obtain tissue lysates, the hippocampus was homogenized in five volumes of ice-cold lysis buffer containing $50 \mathrm{mM}$ Tris- $\mathrm{HCl}$ ( $\mathrm{pH}$ 7.7), $150 \mathrm{mM} \mathrm{NaCl}, 1 \%$ Nonidet P-40, $2 \mathrm{mM}$ EDTA, $0.25 \%$ sodium deoxycholate (DOC), 2 mM EGTA, $0.5 \mathrm{mM}$ phenylmethylsulfonyl fluoride (PMSF), $10 \mu \mathrm{g} / \mathrm{ml}$ 
leupeptin, $1 \mathrm{mM} \mathrm{Na} \mathrm{VO}_{4}, 2 \mathrm{mM} \mathrm{NaF}$, and $2 \mathrm{mM} \mathrm{Na} \mathrm{Na}_{2} \mathrm{O}_{7}$, and incubated on ice for $30 \mathrm{~min}$. Lysate was cleared by centrifugation at $14000 \mathrm{~g}$ for $20 \mathrm{~min}$ and the supernatant was aliquoted and frozen at $-80^{\circ} \mathrm{C}$. This lysate was used for the CaMKII and PP1 enzyme activity assays. For the PKA enzyme activity assay, the tissue was homogenized in icecold Tris-EDTA buffer $(10 \mathrm{mM}$ Tris- $\mathrm{HCl} \mathrm{pH} 7.4$ and $5 \mathrm{mM}$ EDTA) containing protease and phosphatase inhibitors ( $1 \mathrm{mM}$ EGTA, $0.1 \mathrm{mM}$ PMSF, $5 \mu \mathrm{g} / \mathrm{ml}$ aprotinin, $5 \mu \mathrm{g} / \mathrm{ml}$ leupeptin, $0.1 \mathrm{mM} \mathrm{Na} \mathrm{VO}_{4}, 1 \mathrm{mM} \mathrm{NaF}$ ) and centrifuged at $700 \mathrm{~g}$ for $10 \mathrm{~min}$ at $4{ }^{\circ} \mathrm{C}$. The supernatant was transferred to another tube and centrifuged again at $10000 \mathrm{~g}$ for $10 \mathrm{~min}$. The resultant pellet was resuspended in $10 \mathrm{mM}$ Tris- $\mathrm{HCl}$ buffer ( $\mathrm{pH}$ 7.4) containing the mixture of enzyme inhibitors indicated and frozen at $-80^{\circ} \mathrm{C}$ (Dunah et al, 2000). In both cases, protein concentration was determined using the Bio-Rad protein assay with bovine serum albumin as standard.

To obtain membrane-enriched proteins (P2 membrane proteins), the hippocampus was homogenized in ice-cold $10 \mathrm{mM}$ Tris- $\mathrm{HCl}$ (pH 7.4)/5 mM EDTA buffer, containing $320 \mathrm{mM}$ sucrose and the following protease and phosphatase inhibitors: $1 \mathrm{mM}$ EGTA, $0.1 \mathrm{mM} \mathrm{PMSF}, 5 \mu \mathrm{g} / \mathrm{ml}$ aprotinin, $5 \mu \mathrm{g} / \mathrm{ml}$ leupeptin, $0.1 \mathrm{mM} \mathrm{Na} \mathrm{VO}_{4}$, and $1 \mathrm{mM}$ $\mathrm{NaF}$. The homogenate was centrifuged at $700 \mathrm{~g}$ for $10 \mathrm{~min}$, the supernatant was centrifuged again at $37000 \mathrm{~g}$ for $40 \mathrm{~min}$ at $4{ }^{\circ} \mathrm{C}$ and the pellet (P2) was resuspended in $10 \mathrm{mM}$ Tris$\mathrm{HCl}$ in the presence of the indicated enzyme inhibitors (Dunah et al, 2000). The protein concentration was determined (Bio-Rad protein assay) and the aliquots were frozen at $-80^{\circ} \mathrm{C}$.

Aliquots of the P2 membrane preparation were solubilized in nondenaturing conditions by adding 0.1 volumes of $10 \% \mathrm{DOC}$ in $500 \mathrm{mM}$ Tris- $\mathrm{HCl}, \mathrm{pH}$ 9.0, followed by incubation at $36^{\circ} \mathrm{C}$ for $30 \mathrm{~min}$. Then, 0.1 volumes of a buffer containing $1 \%$ Triton X-100, $500 \mathrm{mM}$ Tris- $\mathrm{HCl}(\mathrm{pH}$ 9.0), and the protease and phosphatase inhibitors was added and the preparations were centrifuged at $37000 \mathrm{~g}$ for $40 \mathrm{~min}$ at $4^{\circ} \mathrm{C}$. Aliquots of the supernatant were frozen at $-80^{\circ} \mathrm{C}$. Other aliquots were solubilized in denaturing conditions by adding 0.1 volumes of $20 \%$ sodium dodecyl sulfate (SDS) containing $50 \% \beta$-mercaptoethanol and boiled for $5 \mathrm{~min}$. The denatured preparations were diluted 20 -fold in $50 \mathrm{mM}$ Tris- $\mathrm{HCl}(\mathrm{pH} 7.4) / 0.1 \%$ Triton X-100 buffer in the presence of protease and phosphatase inhibitors and centrifuged at $37000 \mathrm{~g}$ for $10 \mathrm{~min}$ at $4{ }^{\circ} \mathrm{C}$. Aliquots of the supernatant were frozen at $-80^{\circ} \mathrm{C}$.

\section{Western Blotting}

Tissue lysate or P2 membrane proteins $(20 \mu \mathrm{g})$, the latter solubilized in either denaturing and nondenaturing conditions, were separated onto SDS-polyacrylamide gels. Samples were diluted in an equal volume of electrophoresis buffer and boiled for $5 \mathrm{~min}$. Proteins were transferred to a nitrocellulose membrane (Hybond ECL, Amersham Biosciences) using a Trans-Blot ${ }^{\circledR}$ SD semidry (Bio-Rad) system for $30 \mathrm{~min}$ at $12 \mathrm{~V}$. The membranes were blocked with $5 \%$ milk, $0.05 \%$ Tween-20 in PBS for $1.5 \mathrm{~h}$ at room temperature, followed by overnight incubation with the following primary antibodies: mouse monoclonal anti-CaMKII (1:10000, Chemicon), mouse monoclonal anti-phospho-
CaMKII(Thr286) (2 $\mu \mathrm{g} / \mathrm{ml}$, Upstate Biothechnology), rabbit polyclonal anti-PP1 (2 $\mu \mathrm{g} / \mathrm{ml}$, Upstate Biothechnology), and anti- $\alpha$-tubulin (1:20000, Sigma). The membranes were washed three times in PBS/Tween-20 at room temperature, and HRP-conjugated anti-rabbit or anti-mouse antibody (Dako; dilution $1: 1,500$, except for PP-1 that was $1: 3000$ ) was added and incubated for $60 \mathrm{~min}$. Following two washes in PBS/Tween-20 and one in PBS alone, immunolabeled protein bands were detected using an enhanced chemiluminiscence system (ECL Amersham Biosciences), following an autoradiographic exposure to Hyperfilm ${ }^{\mathrm{TM}} \mathrm{ECL}$ (Amersham Biosciences). The quantification of the signals was determined by densitometry using the program ImageMaster I-D (Pharmacia).

\section{Enzyme Assays}

$\mathrm{Ca}^{2+} /$ calmodulin kinase II assay. Analysis of total CaMKII activity was performed using the 'CaMKII Assay Kit' (Upstate Biotechnology) with autocamtide as a selective peptide substrate, in the presence of calcium and calmodulin. The reaction was carried in MOPS assay buffer containing $30-40 \mu \mathrm{g}$ of tissue lysate, $100 \mu \mathrm{M}$ autocamtide, $1 \mathrm{mM} \mathrm{CaCl}_{2}, 8 \mathrm{ng} / \mu \mathrm{l}$ calmodulin, $10 \mu \mathrm{l}$ of a mixture containing PKA and PKC inhibitors $(0.4 \mu \mathrm{M}$ TYADFIASGRTGRRNAI and $0.4 \mu \mathrm{M}$ RFARKGALRQKNV, respectively), and $10 \mu \mathrm{l}$ of $\mathrm{Mg}^{2+} / \mathrm{ATP}$ mixture containing $20 \mathrm{nCi} / \mu \mathrm{l}$ $\left[\gamma-{ }^{32} \mathrm{P}\right]$ ATP (Amersham Biosciences). The mixture was incubated at $30^{\circ} \mathrm{C}$ for $10 \mathrm{~min}$, and the phosphorylated substrate was separated from residual $\left[\gamma_{-}{ }^{32} \mathrm{P}\right]$ ATP using P81 phosphocellulose filters. The filters were rinsed three times with $0.75 \%$ phosphoric acid and one time with acetone, and the bound radioactivity was quantified in a scintillation counter. Blanks to correct for nonspecific binding of $\left[\gamma-{ }^{32} \mathrm{P}\right] \mathrm{ATP}$ to the phosphocellulose paper were run in parallel and CaMKII activity was expressed as $\mathrm{pmol} / \mathrm{min} / \mu \mathrm{g}$ protein. To determine $\mathrm{Ca}^{2+}$-independent CaMKII activity, $1 \mathrm{mM}$ EGTA was added instead of $\mathrm{CaCl}_{2}$.

PP1 assay. Analyses were performed using the 'Protein Serine/Threonine Phosphatase (PSP) Assay Kit' (BioLabs) that quantifies the release of inorganic phosphate from a labeled protein. The substrate used was Myelin Basic Protein (MyBP), labeled with $\left[\gamma-{ }^{32} \mathrm{P}\right] \mathrm{ATP}$ following the kit recommendations. Tissue lysate $(10 \mu \mathrm{l})$, prepared without phosphatase inhibitors, were added to $30 \mu \mathrm{l}$ of assay buffer containing $2 \mathrm{nM}$ okadaic acid and $50 \mu \mathrm{M}$ FK-506 as PP2A and calcineurin inhibitors, respectively. After a preincubation for $5 \mathrm{~min}$ at $30^{\circ} \mathrm{C}$, the reaction was started by adding $10 \mu \mathrm{l}$ of substrate and incubated for $10 \mathrm{~min}$ at $30^{\circ} \mathrm{C}$. The reaction was terminated by adding $200 \mu \mathrm{l}$ of cold $20 \%$ trichloroacetic acid and, after centrifugation at $12000 \mathrm{~g}$, radioactivity was counted in the supernatant. Activity of PP1 was expressed as $\mathrm{pmol} / \mathrm{min} / \mu \mathrm{g}$ protein.

PKA assay. PKA activity was measured by using the 'PKA Assay Kit' (Upstate Biotechnology) with kemptide as substrate. The reaction mixture contained $1.7 \mu \mathrm{M}$ cAMP, $80 \mu \mathrm{M}$ kemptide, $10 \mu \mathrm{l}$ of a mixture containing inhibitors of CaMK and PKC, $10 \mu \mathrm{l}$ of $\mathrm{Mg}^{2+} / \mathrm{ATP}$ mixture containing $\left[\gamma-{ }^{32} \mathrm{P}\right] \mathrm{ATP}$ and $10 \mu \mathrm{l}$ of tissue homogenate in a final volume 
of $60 \mu \mathrm{l}$. After $10 \mathrm{~min}$ at $30^{\circ} \mathrm{C}$, the reaction was terminated by spotting a $25 \mu \mathrm{l}$ aliquot onto phosphocellulose P81 filters. After washing, the bound radioactivity was quantified with a scintillation counter, and PKA activity was expressed as $\mathrm{pmol} / \mathrm{min} / \mu \mathrm{g}$ protein.

\section{Statistical Analysis}

In biochemical studies, results, reported as means $\pm S E M$, were analyzed using ANOVA, and post hoc comparisons were made using the Newman-Keuls test. In passive avoidance studies, nonparametric statistics was used (Kruskal-Wallis ANOVA followed by Mann-Whitney $U$-test).

\section{RESULTS}

\section{Passive Avoidance}

On the training trial, latencies to enter the dark chamber were in general in the range of $1.6-22.5 \mathrm{~s}$, and were not significantly modified after any drug treatment (Table 1). The training latencies of rats used for biochemical experiments were within the same range. The $5-\mathrm{HT}_{1 \mathrm{~A}}$ receptor agonist 8 -OH-DPAT $(0.1 \mathrm{mg} / \mathrm{kg}$ s.c. $)$, administered $30 \mathrm{~min}$ before the acquisition trial, significantly reduced retention latency $24 \mathrm{~h}$ later (Table 1 ). The $5-\mathrm{HT}_{1 \mathrm{~A}}$ receptor antagonist WAY-100635 (0.5 mg/kg i.p.), given $45 \mathrm{~min}$ before the acquisition trial, did not show any intrinsic effect on passive avoidance performance but fully prevented the retention impairment induced by 8 -OH-DPAT (Table 1 ).

\section{CaMKII Levels and Enzyme Activity}

Passive avoidance training did not modify CaMKII immunoreactivity in tissue lysates (Figure 1a). In the P2 membrane preparation, avoidance training induced a significant increase $(\sim 32 \% ; p<0.01)$ in CaMKII levels, which was not observed in shocked untrained rats. In trained rats, there was a significant treatment effect $\left(\mathrm{F}_{3,49}=22.69, \quad p<0.0001\right)$. The effect of training was counteracted by $8-\mathrm{OH}-\mathrm{DPAT}(0.1 \mathrm{mg} / \mathrm{kg})$ and the effect of the $5-\mathrm{HT}_{1 \mathrm{~A}}$ agonist was in turn reversed by the selective antagonist WAY-100635 at a dose $(0.5 \mathrm{mg} / \mathrm{kg})$ without any intrinsic effect (Figure 1b). Neither avoidance training nor

Table I Impairment of Passive Avoidance Retention in Rats by 8-OH-DPAT and Antagonism of the Effect of 8-OH-DPAT by WAY-I00635

\begin{tabular}{lcc}
\hline Treatment & $\begin{array}{c}\text { Training latency } \\
\text { (s) }\end{array}$ & $\begin{array}{c}\text { Retention latency } \\
\text { (s) }\end{array}$ \\
\hline Control & $12.3 \pm 2.4$ & $269.5 \pm 24.4$ \\
WAY-100635 & $14.2 \pm 4.1$ & $277.1 \pm 31.5$ \\
8-OH-DPAT & $10.8 \pm 3.2$ & $61.0 \pm 25.4 *$ \\
WAY-100635 + 8-OH-DPAT & $9.8 \pm 3.5$ & $260.5 \pm 33.0^{\dagger}$ \\
\hline
\end{tabular}

8-OH-DPAT (0.1 mg/kg s.c.) was given $30 \mathrm{~min}$ and WAY-I00635 $(0.5 \mathrm{mg} / \mathrm{kg}$ i.p.) $45 \mathrm{~min}$ before the training session. Retention was measured $24 \mathrm{~h}$ later. Values are means + SEM of I0-30 animals. $* 0<0.0$ I vs control; ${ }^{\dagger} p<0.0$ I vs 8-OH-DPAT (Kruskal-Wallis ANOVA followed by Mann-Whitney U-test).

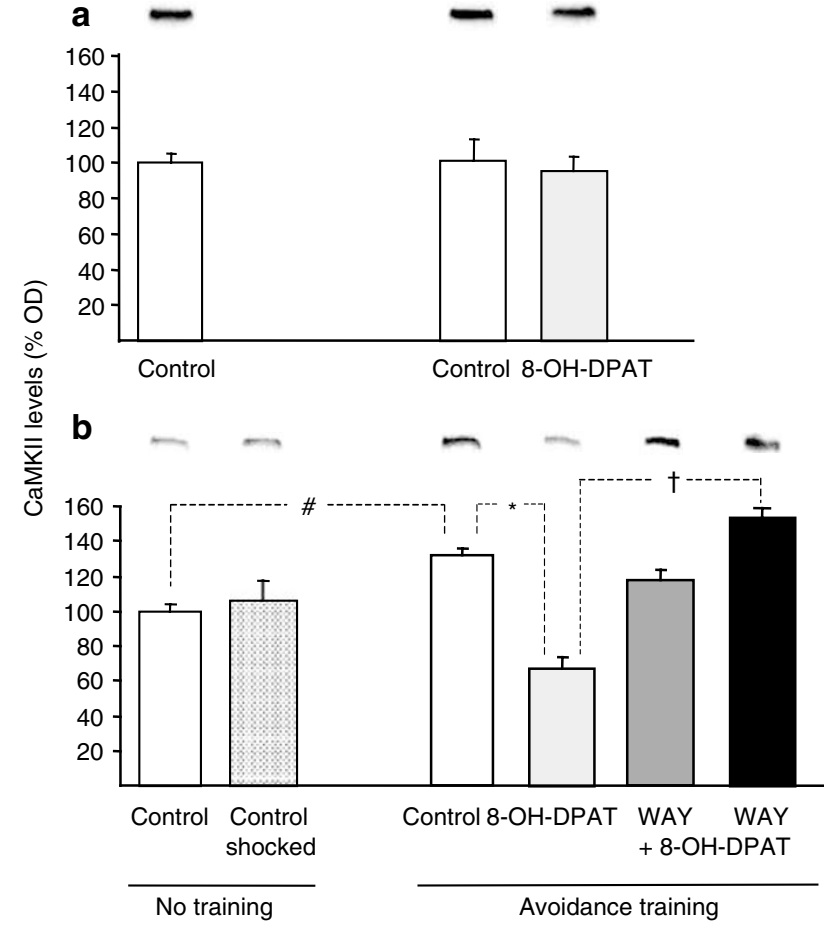

Figure I $\mathrm{Ca}^{2+} /$ calmodulin kinase II (CaMKII) levels in tissue lysates (a) and in solubilized P2 membrane preparations (b) from the hippocampus of rats killed I h after passive avoidance training and of the corresponding nontrained controls. 8-OH-DPAT (0.1 mg/kg s.c.) was given $30 \mathrm{~min}$ and WAY-100635 (0.5 mg/kg i.p.) $45 \mathrm{~min}$ before the acquisition session. All experiments were performed in triplicate. Values, means \pm SEM of 16-20 animals (controls) or 8-12 animals (all other groups), are expressed as percentage of optical density (OD) values of control nontrained rats. ${ }^{\#} p<0.01$ vs control nontrained rats; ${ }^{*} p<0.01$ vs control trained rats; ${ }^{\dagger} p<0.01$ vs $8-\mathrm{OH}$-DPAT-treated rats. Representative scanned hybridized bands are shown at the upper part of the figures. WAY $=$ WAY-100635, $0.5 \mathrm{mg} / \mathrm{kg}$ i.p.

8-OH-DPAT treatment produced any change in $\alpha$-tubulin levels in tissue lysate or in the P2 membrane preparation (not shown).

pCaMKII(Thr286) levels were also measured in tissue lysates and in denaturing membrane extracts. In both cases, phosphorylated protein immunoreactivity was increased to a quite similar extent ( $\sim 36$ and $25 \%$ in tissue lysates and membrane extracts, respectively) after passive avoidance training and not after a noncontingent footshock (Figure $2 \mathrm{a}, \mathrm{b}$ ). In tissue lysates, 8-OH-DPAT prevented the effect of training, and the effect of 8-OH-DPAT was reversed by WAY-100635 $\left(\mathrm{F}_{3,37}=9.47, p<0.0001\right)$. Qualitatively identical effects were found in membrane extracts $\left(\mathrm{F}_{3,44}=7.28, p<0.0001\right)$. In trained rats, the ratio pCaM$\mathrm{KII} / \mathrm{CaMKII}$ in tissue lysates was 1.34 , and went down to 0.85 after 8-OH-DPAT administration. The ratio membrane pCaMKII/tissue lysate CaMKII was 1.24 in control trained rats and 0.99 in rats receiving $8-\mathrm{OH}-\mathrm{DPAT}$.

In enzyme activity assays, total CaMKII activity in the hippocampus of control untrained rats was $0.38 \pm 0.02 \mathrm{pmol} / \mathrm{min} / \mu \mathrm{g}$ protein (mean $\pm \mathrm{SEM}$ of $20 \mathrm{rats}$ ). This enzyme activity was significantly increased by training (mean \pm SEM $=0.53 \pm 0.03 ; n=20 ; p<0.01$ ) and was not modified by a noncontingent shock. The effect of training 


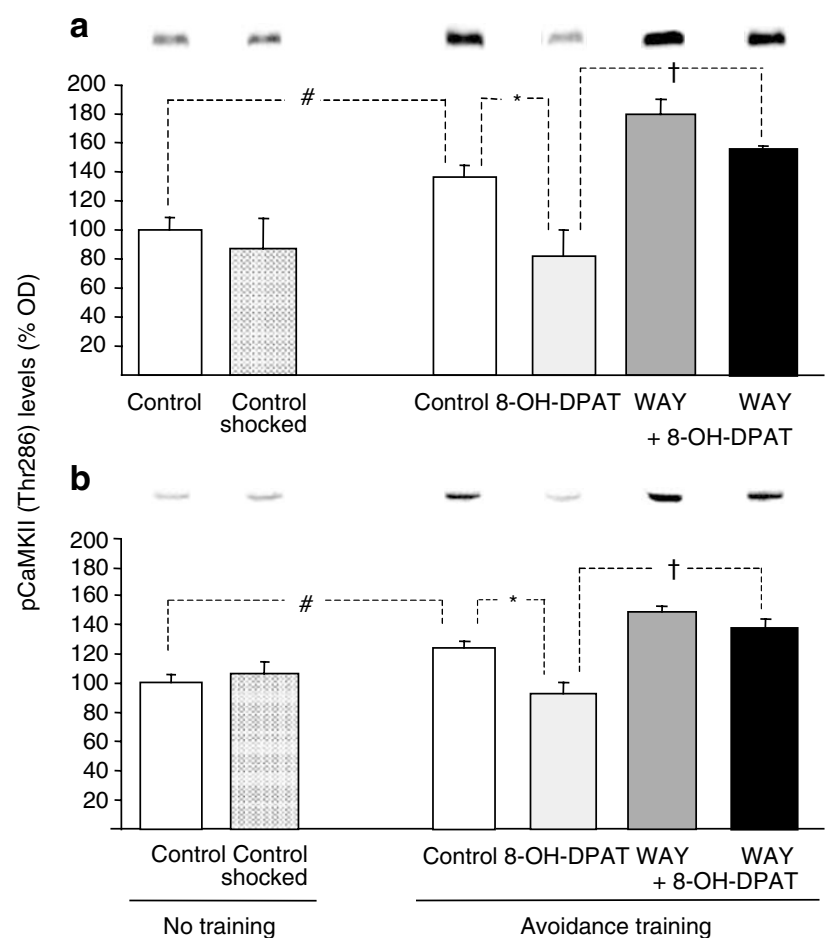

Figure 2 Levels of pCaMKII (Thr-286) in tissue lysates (a) and in solubilized P2 membrane preparations (b) from the hippocampus of rats killed I h after passive avoidance training and of the corresponding nontrained controls. 8-OH-DPAT (0.1 mg/kg s.c.) was given $30 \mathrm{~min}$ and WAY-I00635 (0.5 mg/kg i.p.) $45 \mathrm{~min}$ before the acquisition session. All experiments were performed in triplicate. Values, means \pm SEM of $16-20$ animals (controls) or 8-12 animals (all other groups), are expressed as percentage of optical density (OD) of control nontrained rats. ${ }^{\#} p<0.05$ vs control nontrained rats; ${ }^{*} p<0.05$ vs control trained rats; ${ }^{\dagger} p<0.05$ vs 8 $\mathrm{OH}$-DPAT-treated rats. Representative scanned hybridized bands are shown at the upper part of the figure. WAY $=$ WAY- $100635,0.5 \mathrm{mg} / \mathrm{kg}$ i.p.

was again prevented by 8-OH-DPAT and the effect of the $5-\mathrm{HT}_{1 \mathrm{~A}}$ agonist reversed by WAY-100635 $\left(\mathrm{F}_{3,50}=3.52\right.$, $p=0.022$; see Figure 3a).

$\mathrm{Ca}^{2+}$-independent CaMKII activity was more sensitive than total enzyme activity to the effect of avoidance training, which induced a marked increase $(\sim 78 \%)$ in the activity of the autonomous enzyme from $0.096 \pm 0.005 \mathrm{pmol} / \mathrm{min} / \mu \mathrm{g}$ protein (mean \pm SEM of $16 \mathrm{rats}$ ) to $0.171 \pm 0.014$ (Figure $3 \mathrm{~b}$ ). The ratio autonomous/total CaMKII activity was also increased $(\sim 28 \%)$ by avoidance training. 8-OH-DPAT prevented the effect of training on $\mathrm{Ca}^{2+}$-independent CaMKII activity and WAY-100635 antagonized the effect of 8 -OH-DPAT $\left(\mathrm{F}_{3,38}=4.37, p=0.01\right.$; Figure $3 b$ ).

In untrained rats, which were killed as in the above experiments $90 \mathrm{~min}$ after the same 8-OH-DPAT dose $(0.1 \mathrm{mg} / \mathrm{kg})$, no effect of drug treatment on CaMKII levels or enzyme activity was found. In P2 membranes, protein levels, expressed as percentage of optical density values of control untrained rats, were $107.5 \pm 7.9$ for CaMKII and $95.0 \pm 8.1$ for pCaMKII(Thr286) (means \pm SEM of eight rats). CaMKII enzyme activity in tissue lysates, expressed also as percentage of activity in control untrained rats, was $93.2 \pm 5.1$ and $94.8 \pm 7.7$ for total and $\mathrm{Ca}^{2+}$-independent CaMKII activity, respectively (means \pm SEM of eight rats).
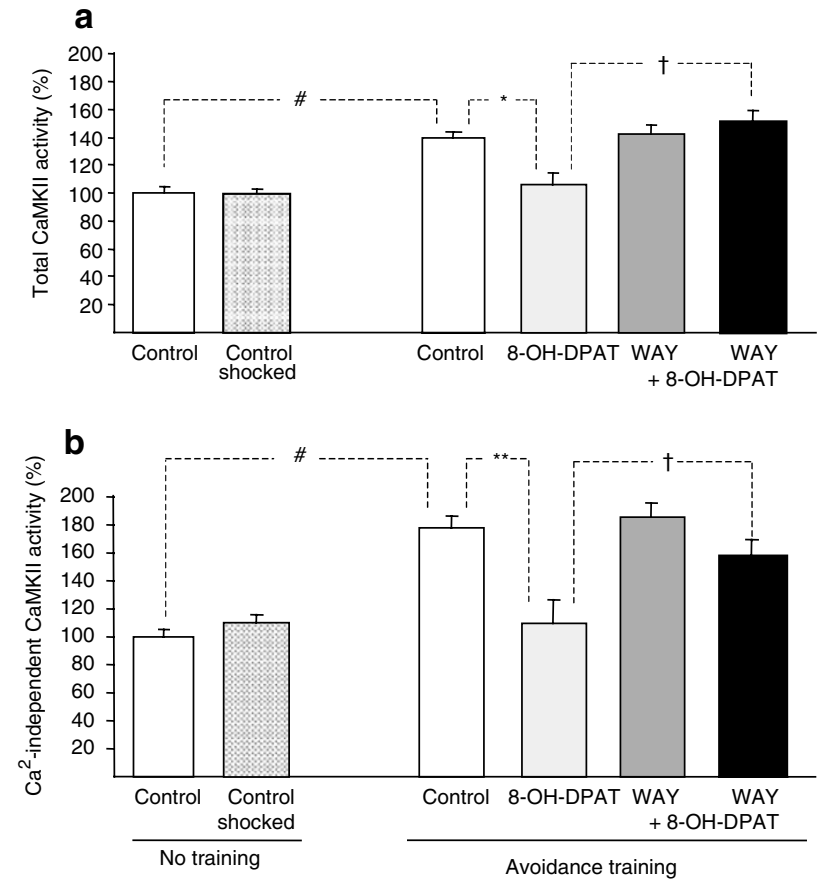

Figure 3 Total $\mathrm{Ca}^{2+} /$ calmodulin kinase $\|$ (CaMKII) activity (a) and $\mathrm{Ca}^{2+}$-independent CaMKII activity (b) in tissue lysates from the hippocampus of rats killed I $\mathrm{h}$ after passive avoidance training and of the corresponding nontrained controls. 8-OH-DPAT (0.I mg $/ \mathrm{kg}$ s.c.) was given $30 \mathrm{~min}$ and WAY-100635 (0.5 mg/kg i.p.) $45 \mathrm{~min}$ before the acquisition session. All experiments were performed in triplicate. Values, means \pm SEM of 16-20 animals (controls) or 8-12 animals (all other groups), are expressed as percentage of CaMKII activity ( $\mathrm{pmol} / \mathrm{min} / \mu \mathrm{g}$ protein) in control nontrained rats. ${ }^{\#} p<0.0$ I vs control nontrained rats; ${ }^{*} p<0.05$, ${ }^{*} *{ }^{*} p<0.01$ vs control trained rats; ${ }^{\dagger} p<0.05$ vs $8-\mathrm{OH}$-DPAT-treated rats. $W A Y=$ WAY-100635, $0.5 \mathrm{mg} / \mathrm{kg}$ i.p.

\section{PP1 Levels and Enzyme Activity}

Passive avoidance training did not induce any significant effect on PP1 immunoreactivity, neither in tissue lysates nor in P2 membrane preparations (Figure 4a, b). No significant increase in PP1 levels in tissue lysates was either found after 8-OH-DPAT administration to trained rats (Figure 4a). A significant treatment effect on membrane PP1 levels was found in trained rats $\left(\mathrm{F}_{3,44}=14.08, p<0.0001\right)$. Membrane PP1 levels were significantly increased by 8 -OH-DPAT ( $\sim 57 \%$ increase), and the effect of 8 -OH-DPAT was prevented by the antagonist WAY-100635 (Figure 4b).

In enzyme activity assays, the method was initially validated with the phosphatase inhibitor okadaic acid $(1 \mu \mathrm{M})$ and different PP1 concentrations to determine the linear range of dephosphorylation. As above, avoidance training did not produce any change in PP1 enzyme activity, which was enhanced by 8-OH-DPAT. There was a significant treatment effect $\left(\mathrm{F}_{3,50}=12.32, p<0.0001\right)$. The effect of 8-OH-DPAT was again prevented by the $5-\mathrm{HT}_{1 \mathrm{~A}}$ antagonist WAY-100635 (Figure 5).

\section{PKA Activity}

The specificity of the method was initially checked by using the PKA inhibitor peptide (PKI) that reduced kinase activity 


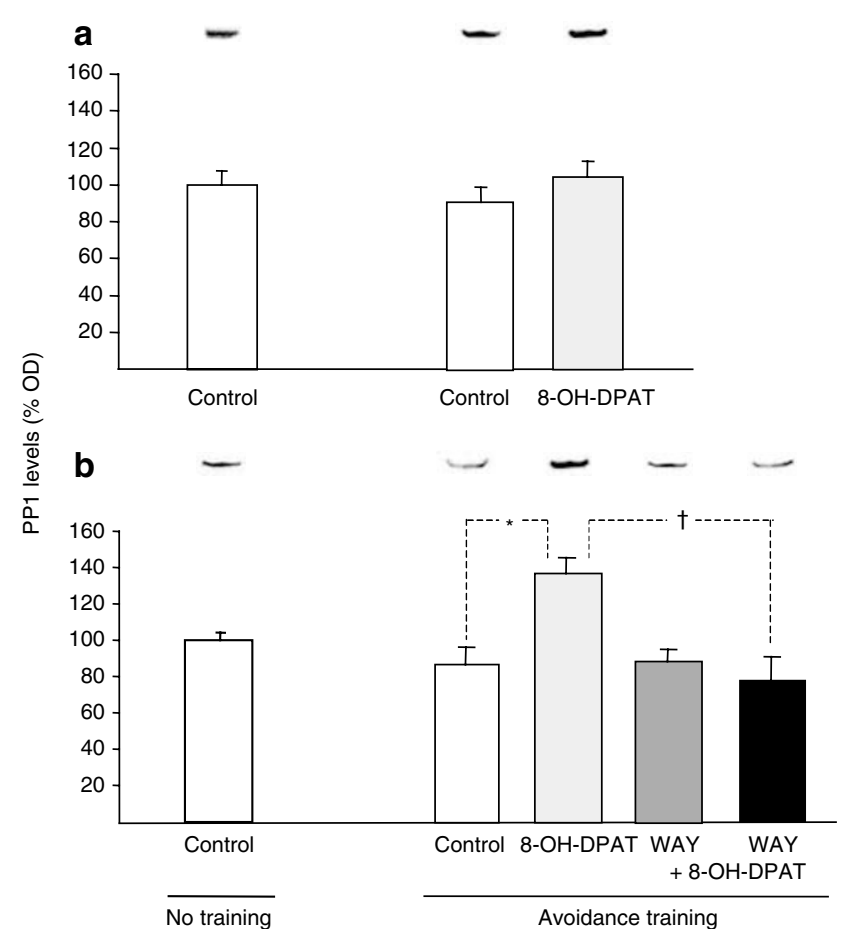

Figure 4 Phosphatase I (PPI) levels in tissue lysates (a) and in solubilized P2 membrane preparations (b) from the hippocampus of rats killed I h after passive avoidance training and of the corresponding nontrained controls. 8-OH-DPAT (0.1 mg/kg s.c.) was given $30 \mathrm{~min}$ and WAY-I00635 (0.5 mg/ $/ \mathrm{kg}$ i.p.) $45 \mathrm{~min}$ before the acquisition session. All experiments were performed in triplicate. Values, means \pm SEM of $16-18$ animals (controls) or 8-12 animals (all other groups), are expressed as percentage of optical density (OD) values of control nontrained rats. ${ }^{*} p<0.0$ I vs control trained rats; ${ }^{\dagger} p<0.01$ vs $8-\mathrm{OH}$-DPAT-treated rats, Representative scanned hybridized bands are shown at the upper part of the figures. WAY $=$ WAY-100635, $0.5 \mathrm{mg} / \mathrm{kg}$ i.p.

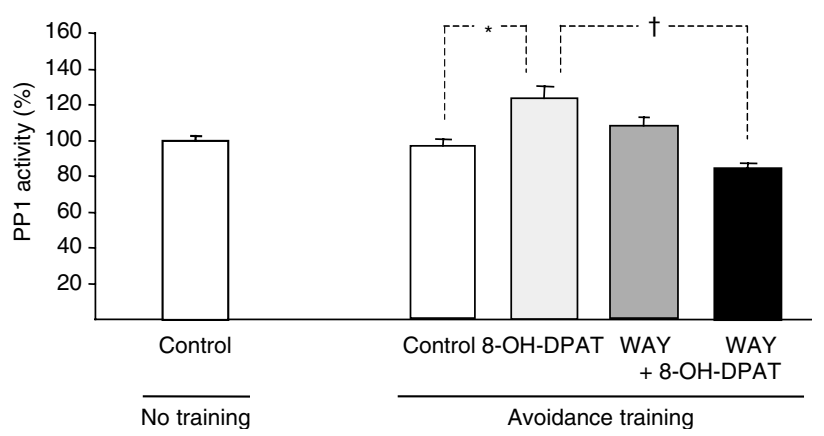

Figure 5 PPI activity in tissue lysates from the hippocampus of rats killed I $\mathrm{h}$ after passive avoidance training and of the corresponding nontrained controls. 8-OH-DPAT (0.I mg/kg s.c.) was given $30 \mathrm{~min}$ and WAY- 100635 $(0.5 \mathrm{mg} / \mathrm{kg}$ i.p.) $45 \mathrm{~min}$ before the acquisition session. All experiments were performed in duplicate. Values, means \pm SEM of I8-22 animals (controls) or 8-12 animals (all other groups), are expressed as percentage of PP I activity $\left(\mathrm{pmol} / \mathrm{min} / \mu \mathrm{g}\right.$ protein) in nontrained control rats. ${ }^{*} p<0.01$ vs control trained rats; ${ }^{\dagger} p<0.01$ vs $8-O H-D P A T-$ treated rats. WAY $=$ WAY100635, $0.5 \mathrm{mg} / \mathrm{kg}$ i.p.

by $90-100 \%$. Passive avoidance training significantly increased enzyme activity (Figure 6). As in previous experiments, footshock did not produce by itself any effect. In trained rats, there was a significant treatment effect $\left(\mathrm{F}_{3,53}=12.98, \quad p<0.0001\right)$. A decrease in PKA activity

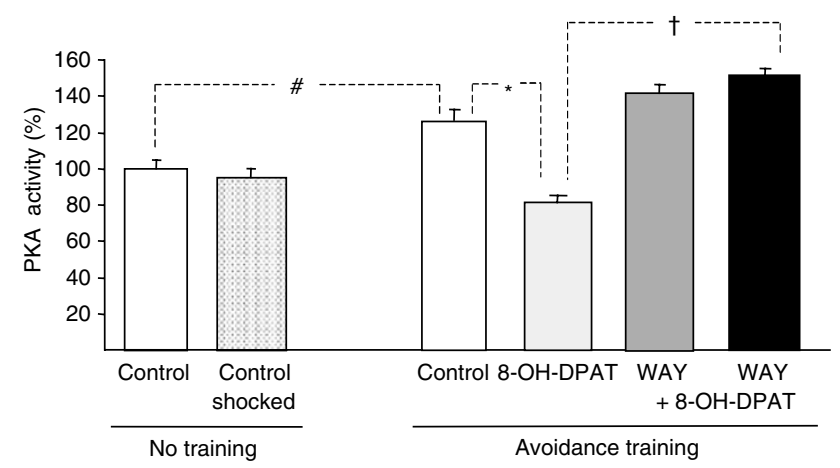

Figure 6 PKA activity in tissue homogenates from the hippocampus of rats killed I h after passive avoidance training and of the corresponding nontrained controls. 8-OH-DPAT (0.1 mg/kg s.c.) was given $30 \mathrm{~min}$ and WAY- 000635 (0.5 mg/kg i.p.) $45 \mathrm{~min}$ before the acquisition session. All experiments were performed in triplicate. Values, means + SEM of $18-22$ animals (controls) or 8-12 animals (all other groups), are expressed as percentage of PKA activity ( $\mathrm{pmol} / \mathrm{min} / \mu \mathrm{g}$ protein) in nontrained control rats. ${ }^{\#} p<0.05$ vs control nontrained rats; ${ }^{*} p<0.05$ vs control trained rats; $p<0.01$ vs $8-O H-D P A T-t r e a t e d$ rats. WAY $=$ WAY-I00635, $0.5 \mathrm{mg} / \mathrm{kg}$ i.p.

$(-35 \%)$ was induced by $8-\mathrm{OH}-\mathrm{DPAT}(0.1 \mathrm{mg} / \mathrm{kg})$ and this effect was reversed by the selective antagonist WAY-100635, $0.5 \mathrm{mg} / \mathrm{kg}$ (Figure 6).

\section{DISCUSSION}

An increase in CaMKII catalytic activity and in the expression of the autophosphorylated form of the enzyme was found in the hippocampus of rats $1 \mathrm{~h}$ after training on a passive avoidance task, and not in rats receiving an identical noncontingent footshock. This increase was prevented by pretraining administration of the $5-\mathrm{HT}_{1 \mathrm{~A}}$ receptor agonist, 8-OH-DPAT, at a dose impairing retention performance. The effects of 8-OH-DPAT on CaMKII activity and retention performance were reversed by the highly selective $5-\mathrm{HT}_{1 \mathrm{~A}}$ receptor antagonist WAY-100635. This antagonist also reversed the 8-OH-DPAT-induced enhancement in PP1 activity, which is probably a determinant of lower phosphorylated CaMKII levels, indicating receptor-specific effects. The results suggest that the $5-\mathrm{HT}_{1 \mathrm{~A}}$ receptormediated disruption of retention performance is a consequence, at least in part, of the reduced phosphorylating activity of CaMKII, a critical mediator of neuronal plasticity and memory.

The impaired retention found after administration of a low dose of 8-OH-DPAT, $0.1 \mathrm{mg} / \mathrm{kg}$, is in keeping with many previous data demonstrating deficits not only in passive avoidance (Carli et al, 1992; Misane et al, 1998; Otano et al, 1999; Santucci and Shaw, 2003) but also in other cognitive tasks such as spatial learning in a water-maze or visual learning in a Y-maze (Carli and Samanin, 1992; Kant et al, 1998; Cassaday et al, 2000). Previous studies from other laboratories (Misane and Ögren, 2000), as well as our previous experiments (Otano et al, 1999), had shown that nonspecific effects, such as changes in locomotor activity or in pain threshold, did not account for the 8-OH-DPATinduced impairment in retention performance. The dose-related retention impairment induced by systemic 
pretraining administration of $8-\mathrm{OH}-\mathrm{DPAT}$ is prevented by selective $5-\mathrm{HT}_{1 \mathrm{~A}}$ receptor antagonists, in particular WAY100635 (Misane and Ögren, 2000, and references therein contained), and seems to be related to an activation of postsynaptic $5-\mathrm{HT}_{1 \mathrm{~A}}$ receptors. In this context, a recent clinical study suggests that postsynaptic $5-\mathrm{HT}_{1 \mathrm{~A}}$ receptors in human hippocampus exert a negative influence on human memory function (Yasuno et al, 2003). This finding is obviously in line with the suggested potential utility of $5-\mathrm{HT}_{1 \mathrm{~A}}$ receptor antagonists in the treatment of cognitive dysfunction (Schechter et al, 2002).

Abundant evidence indicates that CaMKII is an essential biochemical substrate for the early phase of memory formation (Fink and Meyer, 2002). Intracellular calcium elevation after appropriate stimuli causes the enzyme autophosphorylation at Thr286 followed by translocation of the kinase to the postsynaptic density where it binds to the NR1 and NR2B subunits of the NMDA receptor (Leonard et al, 1999; Shen and Meyer, 1999). This binding locks CaMKII in an active, calcium/calmodulin-independent state (Bayer et al, 2001) and provides spatial control of phosphorylation of different postsynaptic proteins implicated in memory formation, particularly the GluR1 subunit of the AMPA receptor (Barria et al, 1997). Consequently, the autophosphorylated enzyme has been proposed to serve as a 'memory molecule' for recent synaptic activity. This process is under regulation by dephosphorylation that leads to the dissociation of CaMKII from the postsynaptic density (Yoshimura et al, 1999). Although CaMKII may be dephosphorylated by either PP1 or PP2A, this process is almost exclusively mediated in the postsynaptic density by PP1 (Strack et al, 1997).

In keeping with previous studies (Cammarota et al, 1998), we found that passive avoidance training increased CaMKII levels in membrane preparations without any change in tissue lysate levels, as well as pCaMKII(Thr286) levels, suggesting a CaMKII translocation to postsynaptic sites. The increase in enzyme activity was also learning-specific, that is, was not influenced by a noncontingent shock, and was much more pronounced for the activated, $\mathrm{Ca}^{2+}$. independent enzyme. Since novelty may influence memory of a passive avoidance task (Izquierdo et al, 1999), the eventual effect on CaMKII of a noncontingent shock after different times of exploration of the dark chamber remains to be established in future studies. While the amount of CaMKII in tissue lysates was unchanged by training, pCaMKII(Thr286) levels were correlated with enzyme activity. It is possible that the lack of correlation between CaMKII levels and total enzyme activity in tissue lysates results from the lower phosphorylation of CaMKII at Thr305/306. These phosphorylations are inhibitory and prevent localization of CaMKII to the postsynaptic density and kinase activity (Hudmon and Schulman, 2002; Lu et al, 2003). All of the learningassociated modifications in CaMKII were effectively prevented by pretraining administration of 8-OH-DPAT, an effect related to $5-\mathrm{HT}_{1 \mathrm{~A}}$ receptor stimulation because it was antagonized by WAY-100635. Similar results were obtained in a recent in vitro study on rat prefrontal cortex pyramidal neurons where $5-\mathrm{HT}$ and $5-\mathrm{HT}_{1 \mathrm{~A}}$ receptor agonists reduced CaMKII activity and AMPA receptor GluR1 phosphorylation (Cai et al, 2002).
Of particular relevance in learning and memory is the regulation of CaMKII function by the cAMP-PKA signaling pathway. PKA indirectly regulates CaMKII by phosphorylation/activation of endogenous inhibitors of PP1 such as Inhibitor-1 and DARPP-32 (dopamine and CAMP-regulated phosphoprotein of $M_{\mathrm{r}} 32 \mathrm{kDa}$ ). These proteins act, when phosphorylated, as potent inhibitors of PP1. Inhibitor-1 is highly expressed in the dentate gyrus of the hippocampus (Gustafson et al, 1991), whereas DARPP-32 is enriched in striatum, although moderate to high levels are also found in several extrastriatal regions, such as the hippocampus (Ouimet et al, 1984). Mice lacking Inhibitor-1 display deficits in LTP induction (Allen et al, 2000), while an enhancement in different forms of hippocampal-dependent memory has been found in mice expressing inducibly a constitutively active form of Inhibitor-1 (Genoux et al, 2002). It has been established that phosphorylated Inhibitor-1, through PP1 activity blockade, maintains an active state of CaMKII at the postsynaptic location (Endo et al, 1996; Shobe, 2002) which may contribute to the effect of this phosphatase inhibitor on memory. It has been shown, on the other hand, that activation of DARPP-32 and the ensuing inhibition of PP-1 activity are of critical importance for the expression of two opposing forms of brain synaptic plasticity, LTD (long-term depression) and LTP (Calabresi et al, 2000). Also, DARPP-32 knockout mice exhibit impaired reversal learning in a discriminated operant task (Heyser et al, 2000). As already mentioned (see Introduction), in the hippocampus $5-\mathrm{HT}_{1 \mathrm{~A}}$ receptors appear to be predominantly coupled through $G_{i}$ proteins to adenylyl cyclase (Schoeffter and Hoyer, 1988), so it is possible that stimulation of these receptors indirectly modify CaMKII activation. Consonant with this possibility and with the above-mentioned in vitro study of Cai et al (2002), the selected 8-OH-DPAT dose produced a significant reduction of PKA activity in rats trained on the passive avoidance task and also a significant increase of PP1 enzyme activity in tissue lysates and protein levels in membranes. A critical event in the retention deficit induced by this $5-\mathrm{HT}_{1 \mathrm{~A}}$ agonist could be a reduced Inhibitor-1/DARPP-32 phosphorylation as a consequence of the lower PKA activity. In line with this hypothesis, a recent study showed that agonists at $5-\mathrm{HT}_{1 \mathrm{~B}}$ receptors, also coupled negatively to adenylyl cyclase, decreased in vitro the phosphorylation of DARPP-32 at the PKA site (Svenningsson et al, 2002).

The reduction of CaMKII activation induced by 8-OH-DPAT in trained rats may influence some of the molecular events related to the kinase activation and involved in later stages of memory formation, such as the increase in NMDA receptor function and the delivery of AMPA receptors to the synapses (Cai et al, 2002). In this regard, it is of interest that the $5-\mathrm{HT}_{1 \mathrm{~A}}$ antagonist, WAY100635, prevents the cognitive deficits caused by NMDA (Boast et al, 1999; Carli et al, 1999) or AMPA receptor blockade (Frechilla et al, unpublished observations). These findings suggest a close relationship between $5-\mathrm{HT}_{1 \mathrm{~A}}$ and glutamate receptors (cf Edegawa et al, 1999). Postsynaptic $5-\mathrm{HT}_{1 \mathrm{~A}}$ receptors are found in dendritic spines (Kia et al, 1996), where glutamate receptors are also concentrated. In the postsynaptic density, highly enriched in NMDA receptors (Kennedy, 1997), the NR1 and NR2B subunits bind to different proteins. Some of them are kinases and 
phosphatases, such as CaMKII and PP1, involved in the modulation of receptor response (Kornau et al, 1995; O'Brien et al, 1998). We here show that these enzymes may be affected in intact rats through $5-\mathrm{HT}_{1 \mathrm{~A}}$ receptormediated mechanisms. The present study provides evidence for early molecular events accounting for the impaired passive avoidance retention induced by $5-\mathrm{HT}_{1 \mathrm{~A}}$ receptor stimulation and suggests the possible beneficial effect of 5$\mathrm{HT}_{1 \mathrm{~A}}$ antagonists in the treatment of cognitive disorders.

\section{ACKNOWLEDGEMENTS}

This study was supported by grants from Ministerio de Ciencia y Tecnología, Spain (BFI 2001-1602) and EC (QLG3CT-2002-00809). We thank Gobierno de Navarra for a fellowship to one of us (SM).

\section{REFERENCES}

Allen PB, Hvalby O, Jensen V, Errington ML, Ramsay M, Chaudhry FA et al (2000). Protein phosphatase-1 regulation in the induction of long-term potentiation: heterogeneous molecular mechanisms. J Neurosci 20: 3537-3543.

Artaiz I, Romero G, Zazpe A, Monge A, Calderó MM, Roca J et al (1995). The pharmacology of VA21B7: an atypical 5- $\mathrm{HT}_{3}$ receptor antagonist with anxiolytic-like properties in animal models. Psychopharmacology 117: 137-148.

Barria A, Muller D, Derkach V, Griffith LC, Soderling TR (1997). Regulatory phosphorylation of AMPA-type glutamate receptors by CaM-KII during long-term potentiation. Science 276: 2042-2045.

Bayer K-U, Koninck PD, Leonard AS, Hell JW, Schulman H (2001). Interaction with the NMDA receptor locks CaMKII in an active conformation. Nature 411: 801-805.

Bliss TV, Collingridge GL (1993). A synaptic model of memory: long-term potentiation in the hippocampus. Nature 361: 31-39.

Blitzer RD, Connor JH, Brown GP, Wong T, Shenolikar S, Iyengar $\mathrm{R}$ et al (1998). Gating of CaMKII by c-AMP-regulated protein phosphatase activity during LTP. Science 280: 1940-1942.

Boast C, Bartolomeo AA, Morris H, Moyer JA (1999). 5-HT antagonists attenuate MK801-impaired radial arm maze performance in rats. Neurobiol Learn Mem 71: 259-271.

Buhot M-C (1997). Serotonin receptors in cognitive behaviors. Curr Opin Neurobiol 7: 243-254.

Cai X, Gu Z, Zhong P, Ren Y, Yan Z (2002). Serotonin 5- $\mathrm{HT}_{1 \mathrm{~A}}$ receptors regulate AMPA receptor channels through inhibiting $\mathrm{Ca}^{2+} /$ calmodulin-dependent kinase II in prefrontal cortical pyramidal neurons. J Biol Chem 277: 36553-36562.

Calabresi P, Gubellini P, Centonze D, Picconi B, Bernardi G, Chergui $\mathrm{K}$ et al (2000). Dopamine and cAMP-regulated phosphoprotein $32 \mathrm{kDa}$ controls both striatal long-term depression and long-term potentiation, opposing forms of synaptic plasticity. J Neurosci 20: 8443-8451.

Cammarota M, Bernabeu R, Levi de Stein M, Izquierdo I, Medina $\mathrm{JH}$ (1998). Learning-specific, time-dependent increases in hippocampal $\mathrm{Ca}^{2+} /$ calmodulin-dependent protein kinase II activity and AMPA GluR1 subunit immunoreactivity. Eur J Neurosci 10: 2669-2676.

Carli M, Samanin R (1992). 8-Hydroxy-2-(di-n-propylamino)tetralin impairs spatial learning in a water maze: role of postsynaptic 5- $\mathrm{HT}_{1 \mathrm{~A}}$ receptors. Br J Pharmacol 105: 720-726.

Carli M, Silva S, Balducci C, Samanin R (1999). WAY 100635, a $5-\mathrm{HT}_{1 \mathrm{~A}}$ receptor antagonist, prevents the impairment of spatial learning caused by blockade of hippocampal NMDA receptors. Neuropharmacology 38: 1165-1173.
Carli M, Tranchina S, Samanin R (1992). 8-Hydroxy-2-(di- $n$ propylamino)tetralin, a $5-\mathrm{HT}_{1 \mathrm{~A}}$ receptor agonist, impairs performance in a passive avoidance task. Eur J Pharmacol 211: 227-234.

Cassaday HJ, Simpson EL, Gaffan EA (2000). Rapid visual learning in the rat: effects at the $5-\mathrm{HT}_{1 \mathrm{~A}}$ receptor subtype. Quart J Exp Psychol B 53: 225-238.

Corradetti R, Ballerini L, Pugliese AM, Pepeu G (1992). Serotonin blocks the long-term potentiation induced by primed burst stimulation in the CA1 region of rat hippocampal slices. Neuroscience 46: 511-518.

Dunah AW, Wang Y, Yasuda RP, Kameyama K, Huganir RL, Wolfe $\mathrm{BB}$ et al (2000). Alterations in subunit expression, composition and phosphorylation of striatal $\mathrm{N}$-methyl-D-aspartate glutamate receptors in a rat 6-hydroxydopamine model of Parkinson's disease. Mol Pharmacol 57: 342-352.

Edegawa Y, Saito H, Abe K (1998). 5- $\mathrm{HT}_{1 \mathrm{~A}}$ receptor-mediated inhibition of long-term potentiation in rat visual cortex. Eur $J$ Pharmacol 349: 221-224.

Edegawa Y, Saito H, Abe K (1999). Stimulation of the 5-HT receptor selectively suppresses NMDA receptor-mediated synaptic excitation in the rat visual cortex. Brain Res 827: 225-228.

Elgersma Y, Silva AJ (1999). Molecular mechanisms of synaptic plasticity and memory. Curr Opin Neurobiol 9: 209-213.

Endo S, Zhou X, Connor J, Wang B, Shenolikar S (1996). Multiple structural elements define the specificity of recombinant human inhibitor-1 as a protein phosphatase-1 inhibitor. Biochemistry 35: 5220-5228.

Fink CC, Meyer T (2002). Molecular mechanisms of CaMKII activation in neuronal plasticity. Curr Opin Neurobiol 12: 293-299.

Genoux D, Haditsch U, Knobloch M, Michalon A, Storm D, Mansuy IM (2002). Protein phosphatase 1 is a molecular constraint on learning and memory. Nature 418: 970-975.

Gustafson EL, Girault JA, Hemmings Jr HC, Nairn AC, Greengard $P$ (1991). Immunocytochemical localization of phosphatase inhibitor-1 in rat brain. J Comp Neurol 310: 170-188.

Heyser CJ, Fienberg AA, Greengard P, Gold LH (2000). DARPP-32 knockout mice exhibit impaired reversal learning in a discriminated operant task. Brain Res 867: 122-130.

Hudmon A, Schulman H (2002). Neuronal $\mathrm{Ca}^{2+} /$ calmodulindependent protein kinase II: the role of structure and autoregulation in cellular function. Annu Rev Biochem 71: 473-510.

Izquierdo I, Medina JH (1997). Memory formation: the sequence of biochemical events in the hippocampus and its connection to activity in other brain regions. Neurobiol Learn Mem 68: $285-316$

Izquierdo I, Schröder N, Netto CA, Medina JH (1999). Novelty causes time-dependent retrograde amnesia for one-trial avoidance in rats through NMDA receptor- and CaMKII-dependent mechanisms in the hippocampus. Eur J Neurosci 11: 3323-3328.

Kant GJ, Wylie RM, Chu K, Ghosh S (1998). Effects of the serotonin agonists 8-OH-DPAT, buspirone, and DOI on water maze performance. Pharmacol Biochem Behav 59: 729-735.

Kennedy MB (1997). The postsynaptic density at glutamatergic synapses. Trends Neurosci 20: 264-268.

Kia HK, Brisorgueil MJ, Hamon M, Calas A, Vergé D (1996). Ultrastructural localization of 5-hydroxytriptamine ${ }_{1 \mathrm{~A}}$ receptors in the rat brain. J Neurosci Res 46: 697-708.

Kornau HC, Schenker LT, Kennedy MB, Seeburg PH (1995). Domain interaction between NMDA receptor subunits and the postsynaptic density protein PSD-95. Science 269: 1737-1740.

Leonard AS, Lim IA, Hemsworth DE, Horne MC, Hell JW (1999). Calcium/calmodulin-dependent protein kinase II is associated with the N-methyl-D-aspartate receptor. Proc Natl Acad Sci USA 96: 3239-3244. 
Liang KC (1999). Pre- or post-training injection of buspirone impaired retention in the inhibitory avoidance task: Involvement of amygdala 5- $\mathrm{HT}_{1 \mathrm{~A}}$ receptors. Eur J Neurosci 11: 1491-1500.

Lu CS, Hodge JJL, Mehren J, Sun XX, Griffith LC (2003). Regulation of the $\mathrm{Ca}^{2+} / \mathrm{CaM}$-responsive pool of CaMKII by scaffold-dependent autophosphorylation. Neuron 40: 1185-1197.

Mazer C, Muneyyirci J, Taheny K, Raio N, Borella A, WhitakerAzmitia P (1997). Serotonin depletion during synaptogenesis leads to decreased synaptic density and learning deficits in the adult rat: a possible model of neurodevelopmental disorders with cognitive deficits. Brain Res 760: 68-73.

Mendelson SD, Quartermain D, Francisco T, Shemer A (1993). $5-\mathrm{HT}_{1 \mathrm{~A}}$ receptor agonists induce anterograde amnesia in mice through a postsynaptic mechanism. Eur J Pharmacol 236: $177-182$.

Milner B, Squire LR, Kandel ER (1998). Cognitive neuroscience and the study of memory. Neuron 20: 445-468.

Misane I, Johansson C, Ögren SO (1998). Analysis of the 5-HT $1 \mathrm{~A}$ receptor involvement in passive avoidance in the rat. $\mathrm{Br} J$ Pharmacol 125: 499-509.

Misane I, Ögren SO (2000). Multiple 5-HT receptors in passive avoidance: comparative studies of $p$-chloroamphetamine and 8-OH-DPAT. Neuropsychopharmacology 22: 168-190.

O’Brien RJ, Lau L-F, Huganir RL (1998). Molecular mechanisms of glutamate receptor clustering at excitatory synapses. Curr Opin Neurobiol 8: 364-369.

Otano A, García-Osta A, Ballaz S, Frechilla D, Del Río J (1999). Facilitation by 8-OH-DPAT of passive avoidance performance in rats after inactivation of $5-\mathrm{HT}_{1 \mathrm{~A}}$ receptors. $\mathrm{Br} \mathrm{J}$ Pharmacol 128 1691-1698.

Ouimet CC, Miller PE, Hemmings HC, Walaas SI, Greengard P (1984). DARPP-32, a dopamine- and adenosine $3^{\prime}: 5^{\prime}$-monophosphate-regulated phosphoprotein enriched in dopamine-innervated brain regions. III. Immunocytochemical localization. J Neurosci 4: 111-124.

Pazos A, Palacios JM (1985). Quantitative autoradiographic mapping of serotonin receptors in the rat brain. I. Serotonin-1 receptors. Brain Res 346: 205-230.

Riedel G, Platt B, Micheau J (2003). Glutamate receptor function in learning and memory. Behav Brain Res 140: 1-47.
Santucci AC, Shaw C (2003). Peripheral 8-OH-DPAT and scopolamine infused into the frontal cortex produce passive avoidance retention impairments in rats. Neurobiol Learn Mem 79: $136-141$.

Schechter LE, Dawson LA, Harder JA (2002). The potential utility of $5-\mathrm{HT}_{1 \mathrm{~A}}$ receptor antagonists in the treatment of cognitive dysfunction associated with Alzheimer's disease. Curr Pharmac Design 8: 139-145.

Schoeffter P, Hoyer D (1988). Centrally acting hypotensive agents with affinity for $5-\mathrm{HT}_{1 \mathrm{~A}}$ binding sites inhibit forskolin-stimulated adenylate cyclase activity in calf hippocampus. $\mathrm{Br} J$ Pharmacol 95: 975-985.

Shen K, Meyer T (1999). Dynamic control of CaMKII translocation and localization in hippocampal neurons by NMDA receptor stimulation. Science 284: 162-166.

Shi SH, Hayashi Y, Esteban JA, Malinow R (2001). Subunit-specific rules governing AMPA receptor trafficking to synapses in hippocampal pyramidal neurons. Cell 105: 331-334.

Shobe J (2002). The role of PKA, CaMKII, and PKC in avoidance conditioning: permissive or instructive? Neurobiol Learn Mem 77: 291-312.

Strack S, Barban MA, Wadzinski BE, Colbran RJ (1997). Differential inactivation of postsynaptic density-associated and soluble $\mathrm{Ca}^{2+} /$ calmodulin-dependent protein kinase II by protein phosphatases 1 and 2A. J Neurochem 58: 2119-2128.

Suzuki T, Okumura-Noji K, Tanaka R, Tada T (1994). Rapid translocation of cytosolic $\mathrm{Ca}^{2+} /$ calmodulin-dependent protein kinase II into postsynaptic density after decapitation. J Neurochem 63: 1529-1537.

Svenningsson P, Tzavara ET, Liu F, Fienberg AA, Nomikos GG, Greengard P (2002). DARPP-32 mediates serotonergic neurotransmission in the forebrain. Proc Natl Acad Sci USA 99: 3188-3193.

Yasuno F, Suhara T, Nakayama T, Ichimiya T, Okubo Y, Takano A et al (2003). Inhibitory effect of hippocampal 5-HT(1A) receptors on human explicit memory. Am J Psychiatry 160: 334-340.

Yoshimura Y, Sogawa Y, Yamauchi T (1999). Protein phosphatase 1 is involved in the dissociation of $\mathrm{Ca}^{2+} /$ calmodulin-dependent kinase II from postsynaptic densities. FEBS Lett 446: 239-242. 